\title{
The $G_{q}$ and $G_{12}$ Families of Heterotrimeric $G$ Proteins Report Functional Selectivity
}

\author{
Li Zhang, Lawrence F. Brass, and David R. Manning \\ From the Departments of Pharmacology (L.Z., D.R.M.) and Medicine (L.F.B.), University of Pennsylvania School of Medicine, \\ Philadelphia, Pennsylvania
}

Received July 29, 2008; accepted October 24, 2008

\begin{abstract}
Receptors coupled to the $\mathrm{G}_{\mathrm{q}}$ and $\mathrm{G}_{12}$ families of heterotrimeric $G$ proteins have surfaced rarely in the context of functional selectivity and always indirectly. We explore here the differential engagement of $G_{q}$ and $G_{13}$ (of the $G_{12}$ family) by the thromboxane $A_{2}$ receptor $\alpha(\operatorname{TP} \alpha)$, via agonist-effected $\left[{ }^{35} \mathrm{~S}\right]-$ guanosine 5'-O-(3-thio)triphosphate binding when the $\mathrm{G}$ proteins themselves are used as reporters. We find for $\operatorname{TP} \alpha$ introduced into human embryonic kidney 293 cells and for the receptor expressed normally in human platelets an agonist-selective engagement of $G_{q}$ versus $G_{13}$. Pinane thromboxane $A_{2}\left(P T A_{2}\right)$ activates $G_{q}$ in preference to $G_{13}$, whereas 8-iso-prostaglandin $F_{2 \alpha}$ activates $G_{13}$ in preference to $G_{\mathrm{q}} \cdot 9,11$ -
\end{abstract}

Dideoxy-9 $\alpha, 11 \alpha$-methanoepoxy-prosta-5Z,13E-dien-1-oic acid (U46619), in contrast, exhibits no preference. Reserve of receptor in relation to $\mathrm{G}$ protein and of $\mathrm{G}$ protein in relation to downstream events is apparent in some instances but does not have a bearing on selectivity. Activation of $G$ proteins by PTA is right-shifted from binding of the ligand to receptor, a manifestation of which is a bimodal action: PTA ${ }_{2}$ is an antagonist at low concentrations and an agonist at higher concentrations. We posit two populations of $\operatorname{TP} \alpha$, or two intrinsic sites of ligand binding, with selectivity evident not only in terms of the $\mathrm{G}$ proteins activated but properties of antagonism versus agonism.
Functional selectivity refers to changes in the conformation of a receptor that are uniquely induced and perceived, respectively, by ligands and effectors specific to the receptor (for reviews, see Perez and Karnik, 2005; Urban et al., 2007). Selectivity is most often evident as differences in the rankorder of ligands in relation to efficacy and/or potency for distinct downstream events. In the case of 7-transmembrane domain receptors, events of interest are those set into motion by heterotrimeric $\mathrm{G}$ proteins, alone or in combination with those engaged by arrestins (Violin and Lefkowitz, 2007).

A great deal of information regarding selectivity has been gained through studies of receptors for serotonin (Berg et al., 1998, 2001; Kurrasch-Orbaugh et al., 2003; De Deurwaerdère et al., 2004), dopamine (Lawler et al., 1999; Kilts et al., 2002; Mottola et al., 2002; Gay et al., 2004; Ryman-Rasmussen et al., 2005), and opiates (Keith et al., 1996, 1998; Whistler et al., 1999; Alvarez et al., 2002), wherein measurements of selectivity as they pertain to $G$

\footnotetext{
This work was supported by National Institutes of Health grant GM066892. Article, publication date, and citation information can be found at http://molpharm.aspetjournals.org.

doi:10.1124/mol.108.050906.
}

proteins are based on increases and decreases in cAMP, stimulation of phosphoinositide metabolism and consequent increases in intracellular calcium, and release of arachidonic acid. In some cases (for example, changes in cAMP and sometimes phosphoinositide metabolism), the G proteins employed are obvious; in others, they are not. Inferences of selectivity through second messengers are blurred to some extent by activities shared among $\mathrm{G}$ proteins, nonlinearity in signal transmission, and the potential in intact cells for cross-regulation of signaling pathways. Several studies have explored, consequently, functional selectivity more directly through measurements of $\mathrm{G}$ protein activation, notably using $\left.{ }^{35} \mathrm{~S}\right]$ guanosine $5^{\prime}-O$-(3-thio)triphosphate $\left(\left[{ }^{35} \mathrm{~S}\right] \mathrm{GTP} \gamma \mathrm{S}\right)$ (Cordeaux et al., 2001) (Cussac et al., 2002) (Lane et al., 2007). Studies using G protein activation are important in that they provide a framework for inferences of receptor conformation that are proximal to the receptor yet operational in nature.

The $\mathrm{G}_{12}$ family of heterotrimeric $\mathrm{G}$ proteins in vertebrates consists of $\mathrm{G}_{12}$ and $\mathrm{G}_{13}$. The family has received considerable attention in studies of cell function, especially cell contractility and adhesion, with targets comprising the monomeric G

ABBREVIATIONS: GTP $\gamma \mathrm{S}$, guanosine 5'-O-(3-thio)triphosphate; TXA $\mathrm{A}_{2}$, thromboxane $\mathrm{A}_{2}$; U46619, 9,11-dideoxy-9 $\alpha, 11 \alpha$-methanoepoxy-prosta5Z,13E-dien-1-oic acid; SQ29548, [1S-[1 $\alpha, 2 \alpha(Z), 3 \alpha, 4 \alpha]]-7-[3-[[2-[($ phenyl amino)carbonyl]hydrazine]methyl]-7-oxabicyclo[2.2.1]hept-2-yl]-5-heptenoic acid; $\mathrm{PTA}_{2}$, pinane-thromboxane $\mathrm{A}_{2} ; 8$-iso-PGF $\mathrm{PG}_{2 \alpha}$, 8-iso-prostaglandin $\mathrm{F}_{2 \alpha}$; HEK, human embryonic kidney; TP, receptor(s) for thromboxane $\mathrm{A}_{2}$; CGP12177, 4-[3-[(1,1-dimethylethyl)amino]-2-hydroxypropoxy]-1,3-dihydro-2H-benzimidazol-2-one. 
protein Rho, cadherins, and Tec tyrosine kinases, among others (for review, see Kelly et al., 2007). The biochemical properties of the $\mathrm{G}_{12}$ family are notable (Singer et al., 1994; Kozasa and Gilman, 1995). One of the most striking aspects of receptors coupled to $\mathrm{G}_{12}$ and/or $\mathrm{G}_{13}$ is that they are invariably coupled to other $G$ proteins as well, almost always $G_{q}$ (Riobo and Manning, 2005). Events elicited through the $\mathrm{G}_{12}$ family are perceived, therefore, to be integrated with events achieved through additional families. In platelets, for example, both thrombin and thromboxane $\mathrm{A}_{2}$ (TXA $\mathrm{TX}_{2}$ ) act on receptors coupled to the $\mathrm{G}_{12}$ and $\mathrm{G}_{\mathrm{q}}$ families. The initial response of platelets to either of the ligands is a change in shape (rounding) that requires $\mathrm{G}_{13}$ (Offermanns, 2006). The change is a prerequisite to degranulation and aggregation, which are achieved subsequently through $\mathrm{G}_{\mathrm{q}}$. The $\mathrm{G}_{\mathrm{q}}$-dependent aggregation is partly mediated through release of ADP by degranulation and subsequent engagement of $G_{i}$. Efficient activation of platelets by thrombin or $\mathrm{TXA}_{2}$, therefore, requires direct engagement of $\mathrm{G}_{\mathrm{q}}$ and $\mathrm{G}_{13}$ and indirect engagement of $G_{i}$.

Given that receptors coupled to $\mathrm{G}_{12}$ and/or $\mathrm{G}_{13}$ invariably couple to other $\mathrm{G}$ proteins, and that the integration of signaling is important, a question of considerable interest is whether agonists working through these receptors exhibit functional selectivity. No studies toward this end have been conducted. A large part of the difficulty is the absence of quantifiable enzymes and second messengers uniquely regulated by the $\mathrm{G}_{12}$ family. In this study, we used [ $\left.{ }^{35} \mathrm{~S}\right] \mathrm{GTP} \gamma \mathrm{S}$ binding to evaluate functional selectivity for agonists operating through the thromboxane $\mathrm{A}_{2}$ receptor $\mathrm{TP} \alpha$. The data reveal, for the first time, selectivity in agonists that engage the $G_{q}$ and $G_{12}$ families of $G$ proteins and reveal as well an unusual bimodal action of a supposed antagonist.

\section{Materials and Methods}

Materials. U46619, SQ29548, pinane thromboxane $\mathrm{A}_{2}\left(\mathrm{PTA}_{2}\right)$, and 8-iso-prostaglandin $\mathrm{F}_{2 \alpha}$ (8-iso- $\mathrm{PGF}_{2 \alpha}$ ) were purchased from Cayman Chemical Company (Ann Arbor, MI). [ ${ }^{35}$ S] GTP $\gamma$ S (1250 $\mathrm{Ci} / \mathrm{mmol})$ and $\left[{ }^{3} \mathrm{H}\right] \mathrm{SQ} 29548(44 \mathrm{Ci} / \mathrm{mmol})$ were purchased from PerkinElmer Life and Analytical Sciences, Inc. (Waltham, MA). Aprotinin, apyrase, normal rabbit serum, GDP, GTP, protein A-Sepharose, and Sepharose 2B were purchased from SigmaAldrich (St. Louis, MO). Pansorbin cells and Nonidet P-40 were purchased from Thermo Fisher Scientific (Waltham, MA). Rabbit antisera for $\mathrm{G} \alpha_{\mathrm{q}}$ and $\mathrm{G} \alpha_{13}$ were produced using peptides corresponding to the $\mathrm{C}$-terminal 10 residues of the two proteins (Butkerait et al., 1995; Windh et al., 1999).

Cells and Membrane Preparation. Human embryonic kidney (HEK) 293 cells stably expressing TP $\alpha$ [4.8 pmol receptor per mg of membrane protein (Wilson et al., 2004)] were maintained in Dulbecco's modified Eagle's medium with $10 \%$ fetal bovine serum and 0.5

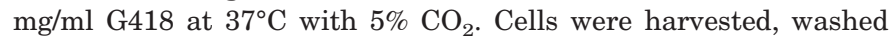
three times with phosphate-buffered saline, and lysed in $20 \mathrm{mM}$ HEPES, pH 8.0, 1 mM EDTA, 0.1\% aprotinin, 0.02\% leupeptin, and $0.1 \%$ phenylmethylsulfonyl fluoride by repeated passage through a 26 -gauge needle. The homogenate was centrifuged at $660 \mathrm{~g}$ for $5 \mathrm{~min}$, and the resultant supernatant was centrifuged at $20,800 \mathrm{~g}$ for $30 \mathrm{~min}$ at $4^{\circ} \mathrm{C}$. The pellet (membrane) was resuspended at $\sim 3 \mathrm{mg} / \mathrm{ml}$ protein.

For platelets, human blood was obtained from healthy donors who denied ingestion of aspirin or any other drug for at least 1 week. The donated blood was collected into a one-sixth volume of a solution containing $65 \mathrm{mM}$ trisodium citrate, $60 \mathrm{mM}$ citric acid, and $100 \mathrm{mM}$ dextrose, $\mathrm{pH}$ 4.4. Platelet-rich plasma was isolated by centrifugation of the citrated blood at $180 \mathrm{~g}$ for $20 \mathrm{~min}$ at room temperature, and platelets were obtained thereafter by sedimentation at $880 \mathrm{~g}$ for 15 min. Platelets were resuspended in a small volume of $10 \mathrm{mM}$ triethanolamine and $5 \mathrm{mM}$ EDTA, $\mathrm{pH} 6.8$, and lysed by immersion in liquid nitrogen then thawing. The lysate was centrifuged at $20,800 \mathrm{~g}$ for $30 \mathrm{~min}$ at $4^{\circ} \mathrm{C}$ to obtain a membrane pellet, which was resuspended at approximately $3 \mathrm{mg} / \mathrm{ml}$ protein in $10 \mathrm{mM}$ triethanolamine, $\mathrm{pH} 6.8$.

$\left[{ }^{35} \mathbf{S}\right]$ GTP $\gamma$ SS-Binding. The assay for agonist-promoted binding of $\left[{ }^{35} \mathrm{~S}\right] \mathrm{GTP} \gamma \mathrm{S}$ to $\mathrm{G} \alpha_{\mathrm{q}}$ and $\mathrm{G} \alpha_{13}$ was performed essentially as described previously (Windh et al., 1999; Zhang et al., 2006). Membranes (20 $\mu \mathrm{g}$ of protein/assay point) were resuspended in $50 \mathrm{mM}$ Tris- $\mathrm{HCl}, \mathrm{pH}$ 7.5, $2 \mathrm{mM}$ EDTA, $100 \mathrm{mM} \mathrm{NaCl}, 20 \mathrm{mM} \mathrm{MgCl}_{2}, 0.1 \mu \mathrm{M}$ GDP, and 5 $\mathrm{nM}\left[{ }^{35} \mathrm{~S}\right] \mathrm{GTP} \gamma \mathrm{S}$ in $1.5-\mathrm{ml}$ microcentrifuge tubes on ice. Ligands, if any, were added, and the tubes were transferred immediately to a $30^{\circ} \mathrm{C}$ water bath for $2\left(\mathrm{G}_{\mathrm{q}}\right)$ or $1\left(\mathrm{G}_{13}\right)$ min. The incubation was terminated by adding $600 \mu \mathrm{l}$ of ice-cold $50 \mathrm{mM}$ Tris-HCl, $\mathrm{pH}$ 7.5, 20

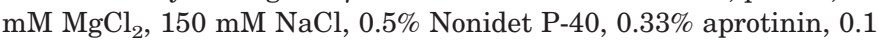
$\mathrm{mM}$ GDP, and $0.1 \mathrm{mM}$ GTP. The extract was transferred to a microcentrifuge tube containing $2 \mu \mathrm{l}$ of nonimmune serum preincubated with $100 \mu \mathrm{l}$ of a $10 \%$ suspension of Pansorbin cells. Nonspecifically bound proteins were removed after $20 \mathrm{~min}$ by centrifugation. The extract was incubated for $1 \mathrm{~h}$ at $4^{\circ} \mathrm{C}$ with $10 \mu \mathrm{l}$ of a $\mathrm{G} \alpha$-directed antiserum or nonimmune serum, both of which had been preincubated with $100 \mu \mathrm{l}$ of a $5 \%$ suspension of protein A-Sepharose. Immunoprecipitates were collected and washed three times in the extraction buffer, then once in the buffer without detergent, and then boiled in $0.5 \mathrm{ml}$ of $0.5 \%$ SDS followed by addition of $5 \mathrm{ml}$ of Ecolite+ (MP Biomedicals, Irvine, CA ). The samples were analyzed directly by scintillation spectrometry. Counts obtained with nonimmune serum, representing nonspecifically bound radiolabel and generally in the range of 50 to $200 \mathrm{cpm}$, were subtracted before portrayal of the data. In experiments involving inhibition of U46619's actions by $\mathrm{PTA}_{2}$, the two ligands were added simultaneously before incubation at $30^{\circ} \mathrm{C}$.

Platelet Shape-Change and Aggregation. Platelet-rich plasma was incubated with $1 \mathrm{mM}$ aspirin and, for experiments relating to shape change (rounding), $0.1 \mathrm{unit} / \mathrm{ml}$ apyrase. Platelets were then isolated by gel filtration on Sepharose 2B using modified Tyrode's buffer (137 mM NaCl, $2.7 \mathrm{mM} \mathrm{KCl,} 1 \mathrm{mM} \mathrm{MgCl}_{2}, 11.9 \mathrm{mM} \mathrm{NaHCO}_{3}, 3.6 \mathrm{mM}$ $\mathrm{NaH}_{2} \mathrm{PO}_{4}, 10 \mathrm{mM}$ HEPES, $0.2 \%$ bovine serum albumin, and $5.5 \mathrm{mM}$ glucose, adjusted $\mathrm{pH}$ to 7.4). Agonist-induced platelet shape-change and aggregation were determined in separate experiments by measuring the transmission of light through a $0.3-\mathrm{ml}$ sample of the aspirin-treated, gel-filtered platelets $\left(2 \times 10^{8}\right.$ cells $\left./ \mathrm{ml}\right)$ with stirring in a lumi-aggregometer (CHRONO-LOG CO., Havertown, PA) at $37^{\circ} \mathrm{C}$ (Prevost et al., 2002). The baseline was set using $0.5 \mathrm{ml}$ of Tyrode's buffer as a blank. Shape-change in response to agonists was evaluated as a decrease in transmission, which was scored as percentage maximum attained; $1 \mu \mathrm{M}$ tirofiban was included in these experiments to prevent aggregation. Aggregation was evaluated (without tirofiban) as an increase in transmission in the presence of $1 \mathrm{mM} \mathrm{CaCl}_{2}$. Aggregation was scored as incidence because of its steeply graded nature.

Meaurement of Cytosolic Calcium. Platelet-rich plasma was incubated with $1 \mathrm{mM}$ aspirin and $5 \mu \mathrm{M}$ Fura-2/acetoxymethyl ester for $1 \mathrm{~h}$ at $37^{\circ} \mathrm{C}$. Platelets were then isolated by gel filtration as described under Cells and Membrane Preparation and, after adjusting to $2 \times 10^{8} \mathrm{cell} / \mathrm{ml}$, were placed into a luminescence spectrometer (PerkinElmer Life and Analytical Sciences). Excitation wavelength was set to $340 \mathrm{~nm}$, and emission was evaluated at a wavelength of $510 \mathrm{~nm}$. Calcium was expressed as concentration using a $K_{\mathrm{d}}$ for Fura-2 of 224 nM (Grynkiewicz et al., 1985).

$\left[{ }^{3} \mathbf{H}\right]$ SQ29548 Displacement. Membranes (20 $\mu \mathrm{g}$ of protein/assay point) were incubated with $20 \mathrm{nM}\left[{ }^{3} \mathrm{H}\right] \mathrm{SQ} 29548$ in the presence or absence of other ligands at specified concentrations in $20 \mathrm{mM}$ HEPES, $\mathrm{pH}$ 7.4, $2 \mathrm{mM}$ EDTA, and $5 \mathrm{mM} \mathrm{NaCl}$ for $30 \mathrm{~min}$ at $30^{\circ} \mathrm{C}$. 
The incubation volume was $0.1 \mathrm{ml}$. Reactions were terminated by dilution with $10 \mathrm{mM}$ HEPES, pH 7.4, and $0.01 \%$ BSA at $0^{\circ} \mathrm{C}$ and rapid filtration over Whatman GF/C filters presoaked in the same buffer. The filters were washed three times with the same buffer at $0^{\circ} \mathrm{C}$ and dried. Filter-bound radioactivity was determined by scintillation spectrometry. Nonspecific binding, generally less than $10 \%$ at $K_{\mathrm{d}}$, was defined as the binding of radioligand in the presence of $100 \mu \mathrm{M}$ SQ29548.

Miscellaneous. Data were analyzed using Prism Software (Graph Pad Software, San Diego, CA). $\left[{ }^{35}\right.$ S $]$ GTP $\gamma$ S-binding was evaluated by nonlinear regression analysis using a logistic equation and a Hill slope of 1 . Displacement of $\left[{ }^{3} \mathrm{H}\right] \mathrm{SQ} 29548$ was fit to a one-site competition mode (a two-site model provided no better fit). Statistical differences in $\mathrm{EC}_{50}$ or $K_{\mathrm{i}}$ values were determined using a twotailed Student's $t$ test, $p<0.05$ signifying a difference.

\section{Results}

Most receptors that are coupled to $G$ proteins of the $G_{12}$ family couple to those of the $G_{q}$ family as well. Despite the importance of these receptors and the general interest in functional selectivity, differences in engagement of the two $G$ protein families have not been investigated. Studies were initiated here with $\mathrm{TP} \alpha$, a receptor for $\mathrm{TXA}_{2}$, and the $\mathrm{G}$ proteins $G_{q}$ and $G_{13} . G_{13}$ is a member of the $G_{12}$ family, the actions of which are essential to those of $\mathrm{TP} \alpha$ in platelets. The ligands employed were U46619, $\mathrm{PTA}_{2}$, and 8-iso-PGF ${ }_{2 \alpha}$.

The activation of $\mathrm{G}_{\mathrm{q}}$ and $\mathrm{G}_{13}$ through TP $\alpha$ was evaluated first with HEK 293 cells in which TP $\alpha$ was introduced and stably expressed (Wilson et al., 2004). Activation was evaluated as ligand-promoted binding of $\left[{ }^{35} \mathrm{~S}\right] \mathrm{GTP} \gamma \mathrm{S}$ to endogenous $\mathrm{G} \alpha$ subunits. $\mathrm{U} 46619, \mathrm{PTA}_{2}$, and 8-iso- $\mathrm{PGF}_{2 \alpha}$ all activated $\mathrm{G}_{\mathrm{q}}$ and, as we reported previously (Zhang et al., 2006), $\mathrm{G}_{13}$ (Fig. 1). U46619 was the most potent, exhibiting an $\mathrm{EC}_{50}$ of approximately $80 \mathrm{nM}$ for both G proteins (Table 1). $\mathrm{PTA}_{2}$ was more potent than 8-iso-PGF ${ }_{2 \alpha}$ in activating $\mathrm{G}_{\mathrm{q}}$, whereas the two were similar in activating $\mathrm{G}_{13}$. It is noteworthy that $\mathrm{PTA}_{2}$ activated $\mathrm{G}_{\mathrm{q}}$ in preference to $\mathrm{G}_{13}\left(\mathrm{EC}_{50}=1 \mu \mathrm{M}\right.$ for $\mathrm{G}_{\mathrm{q}}$ versus $4.5 \mu \mathrm{M}$ for $\mathrm{G}_{13}, p=0.03$ ), whereas the converse was true for 8-iso- $\mathrm{PGF}_{2 \alpha}\left(\mathrm{EC}_{50}=3.4 \mu \mathrm{M}\right.$ for $\mathrm{G}_{13}$ versus $12 \mu \mathrm{M}$ for $\mathrm{G}_{\mathrm{q}}, p=0.04$ ). Activation in membranes of cells where $\mathrm{TP} \alpha$ was not introduced was negligible. These data, in which opposite preferences for effectors ( $G$ proteins) by two agonists were observed, connote functional selectivity.

We turned to human platelets, for which TP $\alpha$ and the G proteins are both endogenous (the existence of $\mathrm{TP} \beta$ as well in platelets is a possibility, hence the term 'TP' hereafter, but see Habib et al., 1999). U46619, $\mathrm{PTA}_{2}$, and 8-iso-PGF ${ }_{2 \alpha}$ again activated $G_{\mathrm{q}}$ and $\mathrm{G}_{13}$ (Fig. 2). U46619 remained the most potent of the three and did not distinguish between the two $G$ proteins $\left(\mathrm{EC}_{50}=0.3-0.4 \mu \mathrm{M}\right)$. $\mathrm{PTA}_{2}$ was more potent than 8-iso-PGF ${ }_{2 \alpha}$ in activating $\mathrm{G}_{\mathrm{q}}$, although it was less efficacious. $\mathrm{PTA}_{2}$ and 8-iso-PGF $\mathrm{PG}_{2 \alpha}$ activated $\mathrm{G}_{13}$ with similar potency, but here 8 -iso-PGF $\mathrm{PG}_{2 \alpha}$ was the less efficacious. Selectivity referenced to potency was again evident: PTA $_{2}$ activated $\mathrm{G}_{\mathrm{q}}$ in preference to $\mathrm{G}_{13}\left(\mathrm{EC}_{50}=3 \mu \mathrm{M}\right.$ for $\mathrm{G}_{\mathrm{q}}$ versus $14 \mu \mathrm{M}$ for $\mathrm{G}_{13}, p=0.008$ ), whereas 8-iso- $\mathrm{PGF}_{2 \alpha}$ activated $\mathrm{G}_{13}$ in preference to $\mathrm{G}_{\mathrm{q}}\left(\mathrm{EC}_{50}=35 \mu \mathrm{M}\right.$ for $\mathrm{G}_{13}$ versus $210 \mu \mathrm{M}$ for $\mathrm{G}_{\mathrm{q}}, p=$ 0.003). Activation of the two $G$ proteins by all three ligands was blocked by the TP antagonist SQ29548 (data not shown). The selectivity noted upon overexpression of TP $\alpha$ in HEK 293 cells, therefore, was corroborated in a setting where receptor and $G$ proteins are expressed normally.
One of the reasons for measuring selectivity using $G$ proteins is that the phenomenon is less likely to be obscured by idiosyncrasies in signal propagation and regulation attending downstream events. With this in mind, we

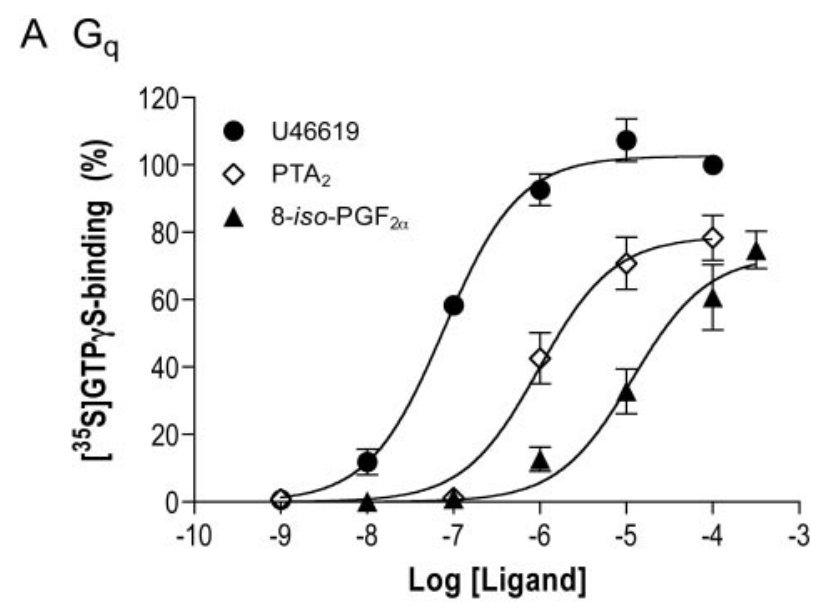

B $\mathrm{G}_{13}$

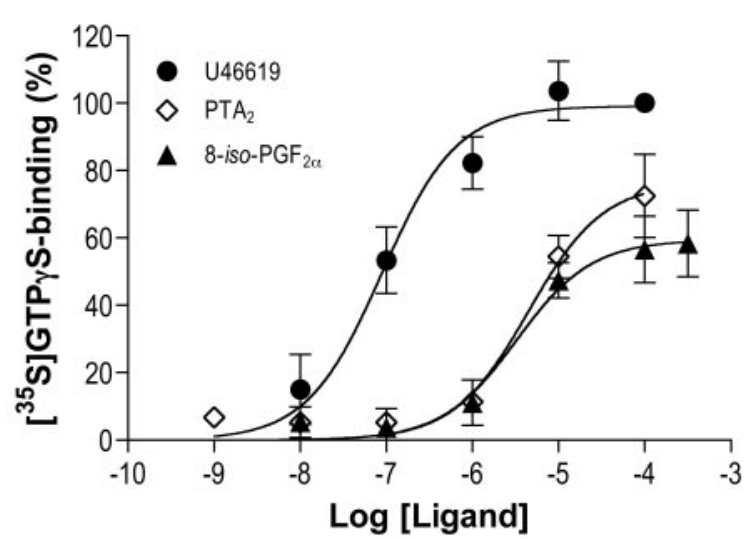

Fig. 1. Activation of $G_{q}$ and $G_{13}$ through TP $\alpha$ in HEK 293 cell membranes. Membranes were prepared from HEK 293 cells stably expressing $\mathrm{TP} \alpha$ and incubated with U46619, $\mathrm{PTA}_{2}$, and 8-iso- $\mathrm{PGF}_{2 \alpha}$ at the concentrations indicated, together with $\left.{ }^{35} \mathrm{~S}\right] \mathrm{GTP} \gamma \mathrm{S}$. Binding of $\left[{ }^{35} \mathrm{~S}\right] \mathrm{GTP} \gamma \mathrm{S}$ to $\mathrm{G} \alpha$ subunits of endogenous $\mathrm{G}_{\mathrm{q}}(\mathrm{A})$ and $\mathrm{G}_{13}(\mathrm{~B})$ was determined by immunoprecipitation with $\mathrm{G} \alpha$-selective antibodies and scintillation spectrometry. The data are expressed as a percentage binding obtained with $100 \mu \mathrm{M}$ U46619, equivalent to approximately $3000 \mathrm{cpm}$ for $\mathrm{G}_{\mathrm{q}}$ and $500 \mathrm{cpm}$ for $\mathrm{G}_{13}$, minus binding in the absence of agonist, approximately $150 \mathrm{cpm}$. Each point represents the mean \pm S.E. of three to five independent experiments.

TABLE 1

Potency of ligands in promoting activation of $\mathrm{G}_{\mathrm{q}}$ and $\mathrm{G}_{13}$ through TP $\alpha$ The activation of $G_{\mathrm{q}}$ and $\mathrm{G}_{13}$ was evaluated in membranes of HEK 293 cells stably (over)expressing TP $\alpha$ and membranes of human platelets. $\mathrm{EC}_{50}$ values for $\mathrm{U} 46619$, $\mathrm{PTA}_{2}$, and 8-iso-PGF $2 \alpha$ were determined by nonlinear regression on concentrationresponse data. Each value is the average of three to five experiments, with $95 \%$ confidence intervals (C.I.) given in parentheses. $P$ values for comparisons between $G_{\mathrm{q}}$ and $\mathrm{G}_{13}$ for individual ligands are also noted.

\begin{tabular}{|c|c|c|c|}
\hline & \multicolumn{2}{|c|}{$\mathrm{EC}_{50}(95 \%$ C.I. $)$} & \multirow{2}{*}{$P$} \\
\hline & $\mathrm{G}_{\mathrm{q}}$ & $\mathrm{G}_{13}$ & \\
\hline & \multicolumn{2}{|c|}{$\mu M$} & \\
\hline \multicolumn{4}{|l|}{ HEK $293 / \mathrm{TP} \alpha$} \\
\hline U46619 & $0.078(0.058-0.10)$ & $0.089(0.049-0.16)$ & 0.8 \\
\hline $\mathrm{PTA}_{2}$ & $1(0.53-1.8)$ & $4.5(1.9-10)$ & 0.03 \\
\hline 8-iso-PGF ${ }_{2} \alpha$ & $12(5.9-24)$ & $3.4(1.7-7.2)$ & 0.04 \\
\hline \multicolumn{4}{|l|}{ Platelets } \\
\hline U46619 & $0.39(0.35-0.45)$ & $0.31(0.24-0.39)$ & 0.1 \\
\hline $\mathrm{PTA}_{2}$ & $3.1(1.7-5.6)$ & $14(8.1-25)$ & 0.008 \\
\hline 8-iso-PGF ${ }_{2} \alpha$ & $210(110-400)$ & $35(20-64)$ & 0.003 \\
\hline
\end{tabular}


examined platelet rounding and aggregation, respectively, as correlates of $\mathrm{G}_{13}$ and $\mathrm{G}_{\mathrm{q}}$ activation. All three ligands, as expected, caused rounding (Fig. 3, top). The $\mathrm{EC}_{50}$ values were shifted leftward 10- to 20-fold from those for $G_{13}$ activation, suggesting either a surplus of $\mathrm{G}_{13}$ in relation to downstream events (analogous to receptor reserve) or a better coupling of receptor and G protein in the intact cell. The maximal effects of the three ligands were similar. Rounding caused by the ligands was inhibited by SQ29548. Activation of $\mathrm{G}_{13}$ through one or more forms of TP by all three ligands translates, therefore, into a physiological response. This was not the case for aggregation.

U46619 elicited, as expected, aggregation (Fig. 3, middle), which was steeply graded and inhibited by SQ29548. The $\mathrm{EC}_{50}$ for aggregation (135 $\mathrm{nM}$ ) was close to that for activation of $G_{q}$ in membranes, suggesting little if any $G_{q}$ reserve. $\mathrm{PTA}_{2}$, however, did not effect aggregation at any but the highest concentration tested $(300 \mu \mathrm{M})$, and the aggregation was not inhibited by SQ29548, indicating the effect to be nonspecific. 8-iso-PGF ${ }_{2 \alpha}$ was without effect altogether. The activation of $\mathrm{G}_{\mathrm{q}}$ noted for $\mathrm{PTA}_{2}$ and 8-iso- $\mathrm{PGF}_{2 \alpha}$ through TP, therefore, was inconsequential to aggregation. The ability of

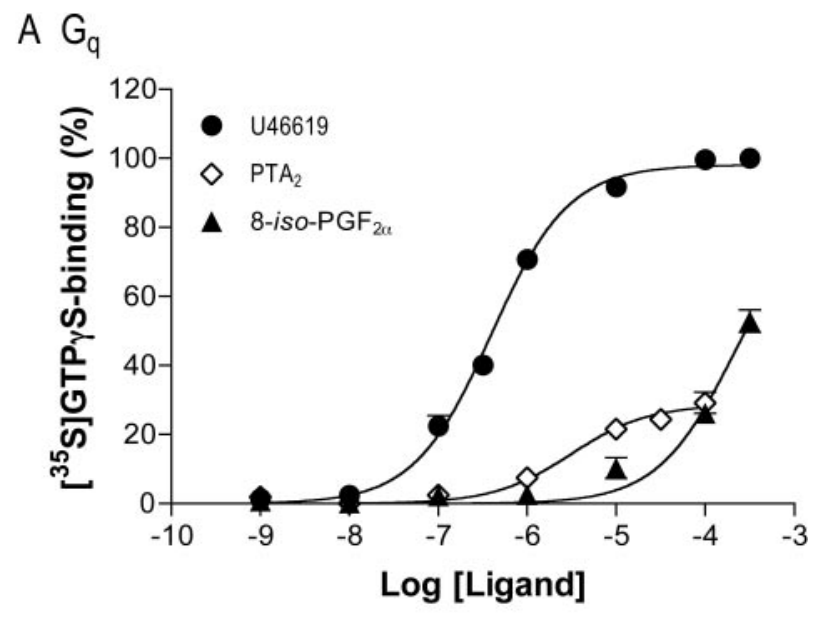

$B G_{13}$

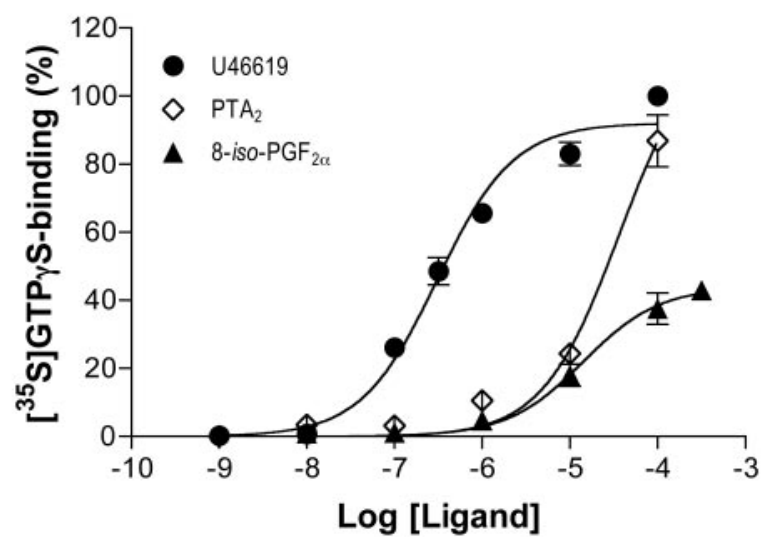

Fig. 2. Activation of $G_{q}$ and $G_{13}$ through TP in platelet membranes. Membranes were prepared from human platelets, and the activation of $\mathrm{G}_{\mathrm{q}}$ (A) and $\mathrm{G}_{13}$ (B) in response to $\mathrm{U} 46619, \mathrm{PTA}_{2}$, and 8-iso-PGF $\mathrm{PG}_{2 \alpha}$ was evaluated as described in the legend to Fig. 1. The data are expressed as a percentage binding obtained with $100 \mu \mathrm{M}$ U46619, equivalent to approximately $8000 \mathrm{cpm}$ for $\mathrm{G}_{\mathrm{q}}$ and $1500 \mathrm{cpm}$ for $\mathrm{G}_{13}$, minus binding in the absence of agonist, approximately $500 \mathrm{cpm}$. Each point represents the mean \pm S.E. of three to five independent experiments.
U46619 to effect aggregation was paralleled by its ability to effect a substantial increase in intracellular calcium (Fig. 3, bottom panel). We suspect that the inability of $\mathrm{PTA}_{2}$ and 8 -iso-PGF ${ }_{2 \alpha}$ to effect aggregation or large increases in calcium through one or more forms of $\mathrm{TP}$ is due to a required threshold in $G_{q}$ activation. The selectivity noted for $G$ protein activation was, nonetheless, not evident in downstream events, underscoring the problems inherent to these events as measures of the phenomenon.

Selectivity can explain preferential engagement of one $G$ protein or another by a ligand, but it has the ability to explain other actions as well. Contrary to the above-noted properties of $\mathrm{PTA}_{2}$ as an activator of $\mathrm{G}$ proteins through $\mathrm{TP} \alpha$, $\mathrm{PTA}_{2}$ is most often viewed to be an antagonist of the receptor (for example Nicolaou et al., 1979; Nie et al., 2008). We
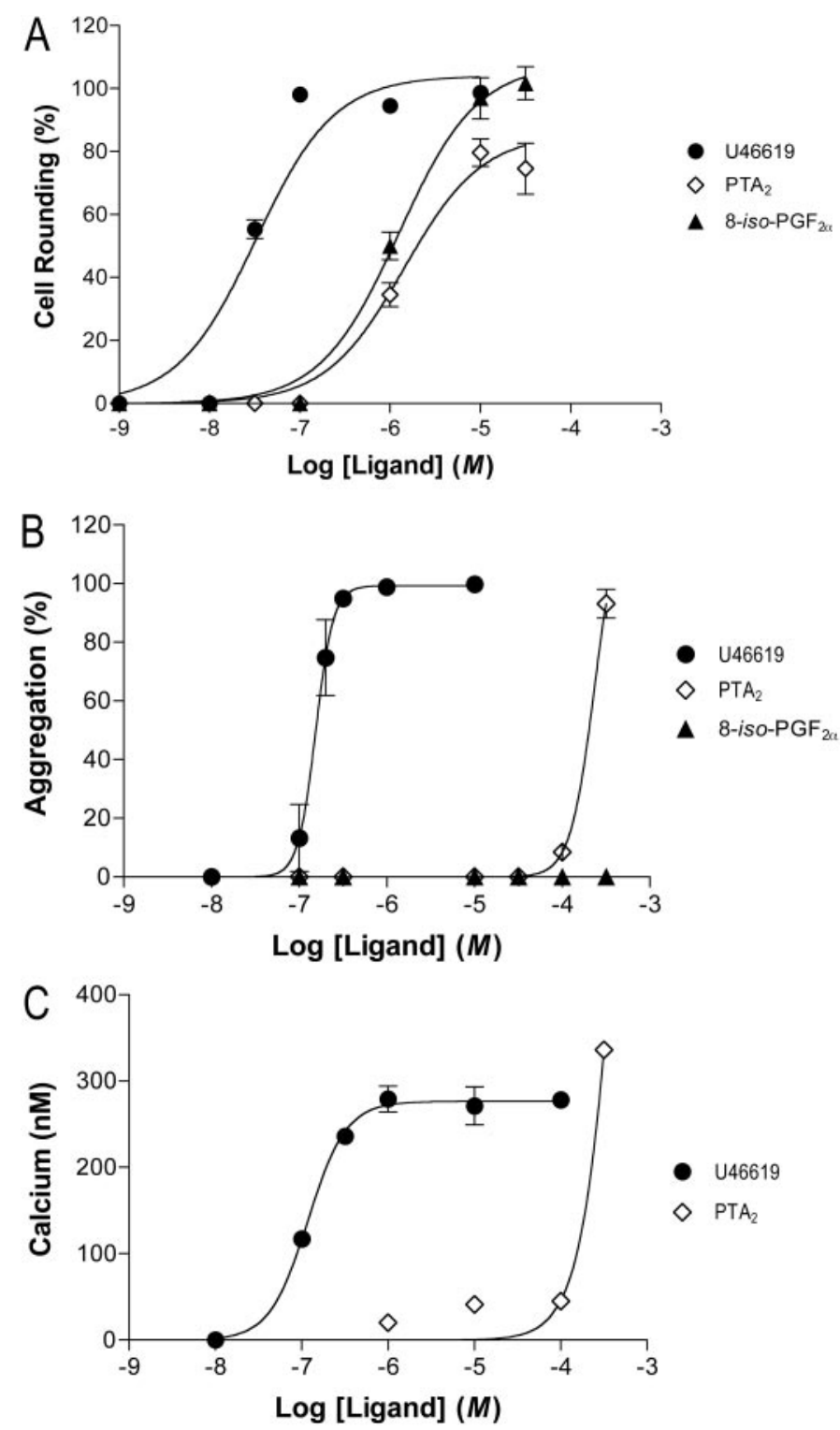

Fig. 3. Response of intact platelets to ligands for TP. The response of human platelets to U46619, $\mathrm{PTA}_{2}$, and 8 -iso-PGF $2 \alpha$ was evaluated in terms of cell rounding (top), aggregation (middle), and intracellular calcium (bottom; data for U46619 and $\mathrm{PTA}_{2}$ only). Rounding and aggregation are expressed as a percentage of that obtained with $10 \mu \mathrm{M}$ U46619. Each point represents the mean \pm S.E. of three to five independent experiments. 
wondered whether the difference between our results and cited actions of $\mathrm{PTA}_{2}$ as an antagonist might rest with a confusion of weak agonism for antagonism, at least at the level of $G_{q}$, or with functional selectivity of some form. We found that PTA $_{2}$ inhibited the activation of $\mathrm{G}_{\mathrm{q}}$ by $\mathrm{U} 46619$ (Fig. 4, top), and that the activity at the highest concentration of $\mathrm{PTA}_{2}(10 \mu \mathrm{M})$ was that of $\mathrm{PTA}_{2}$ alone. This finding conforms to what one would expect for a partial agonist. Of interest, however, was what seemed to be the unusual potency of $\mathrm{PTA}_{2}$ with respect to inhibition: the $\mathrm{IC}_{50}$ was $0.5 \mu \mathrm{M}$ when $\mathrm{PTA}_{2}$ was tested against $1 \mu \mathrm{M}$ U46619, implying an affinity for receptor slightly greater than that of U46619 itself. This finding was in distinction to the data for $\mathrm{G}$ protein activation, in which the potency of $\mathrm{PTA}_{2}$ was 8-fold less than that of U46619. The distinction was even more striking when the activation of $\mathrm{G}_{13}$ was evaluated. $\mathrm{PTA}_{2}$ is a full agonist with regard to $G_{13}$, hence suppression of U46619-promoted activation by $\mathrm{PTA}_{2}$ should not be discernible. This was not the case. PTA $_{2}$ inhibited U46619-effected activation of $\mathrm{G}_{13}$ with an $\mathrm{IC}_{50}$ of $0.7 \mu \mathrm{M}$ (Fig. 4 , bottom), well below the $\mathrm{EC}_{50}$ $(14 \mu \mathrm{M})$ for its activation of $\mathrm{G}_{13}$. The effects of $\mathrm{PTA}_{2}$ in the presence of U46619 were biphasic (not shown), with the inhibition at low concentrations followed by an activation analogous to that noted previously for $\mathrm{PTA}_{2}$ alone at higher concentrations. $\mathrm{PTA}_{2}$, therefore, displayed concentration-
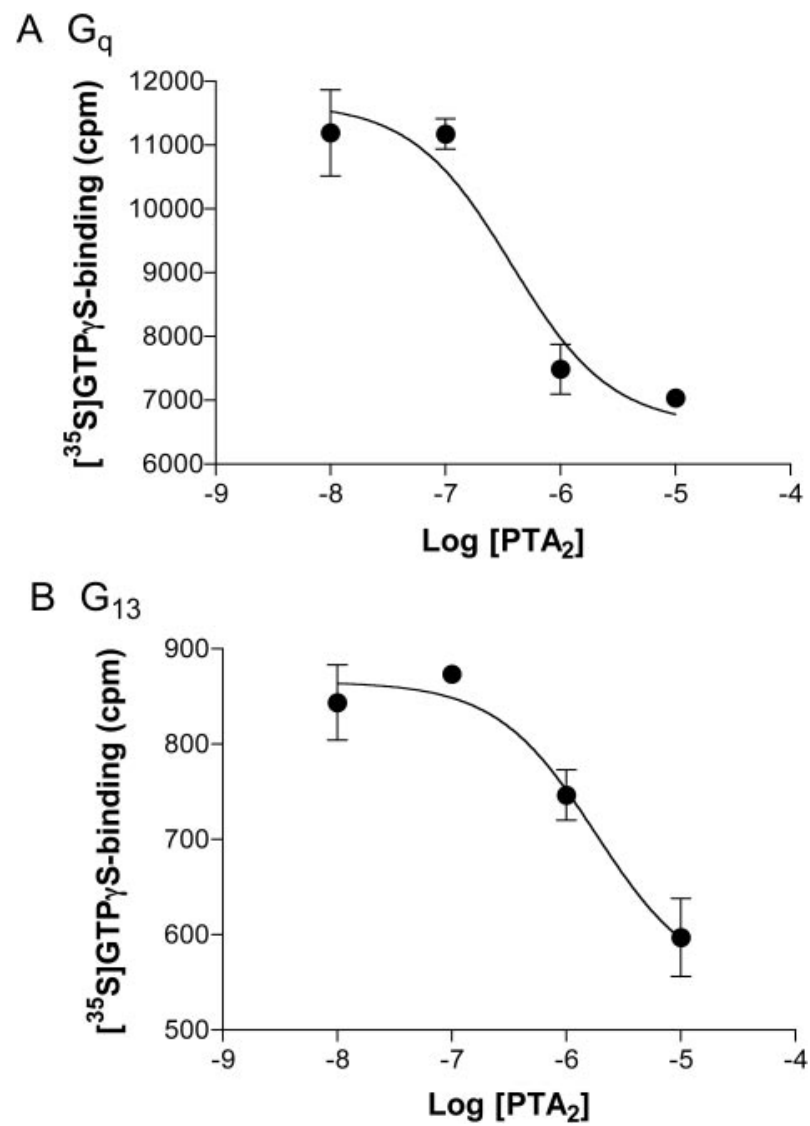

Fig. 4. Inhibition by $\mathrm{PTA}_{2}$ of $\mathrm{U} 46619$ 's activation of $\mathrm{G}_{\mathrm{q}}$ and $\mathrm{G}_{13}$ in platelet membranes. Membranes from human platelets were incubated with 1 $\mu \mathrm{M}$ U46619, the indicated concentrations of $\mathrm{PTA}_{2}$, and $\left[{ }^{35} \mathrm{~S}\right] \mathrm{GTP} \gamma \mathrm{S}$. Binding of $\left[{ }^{35} \mathrm{~S}\right] \mathrm{GTP} \gamma \mathrm{S}$ to $\mathrm{G} \alpha_{\mathrm{\alpha}}$ and $\mathrm{G} \alpha_{13}$ was evaluated as described in the legend to Fig. 2. The data are from single experiments performed in duplicate, which are representative of two others each for $G_{q}$ and $G_{13}$, and are expressed as counts per minute. dependent opposing actions at the level of each of the two G proteins.

To help clarify the behavior of $\mathrm{PTA}_{2}$, we evaluated the affinity displayed by $\mathrm{U} 46619$ and $\mathrm{PTA}_{2}$ for receptor(s) on platelet membranes by displacement assays using $\left[{ }^{3} \mathrm{H}\right]$ SQ29548. The $K_{\mathrm{i}}$ for SQ29548 with platelet membranes was $40 \mathrm{nM}$ (Table 2). Both $\mathrm{U} 46619$ and $\mathrm{PTA}_{2}$ displaced the radiolabel with $K_{\mathrm{i}}$ values of 0.7 and $0.4 \mu \mathrm{M}$, respectively (Fig. 5 and Table 2). In the case of U46619, therefore, binding was roughly coincident with activation of $\mathrm{G}_{\mathrm{q}}$ and $\mathrm{G}_{13}\left(\mathrm{EC}_{50}=\right.$ 0.3-0.4 $\mu \mathrm{M}$, as noted above). For $\mathrm{PTA}_{2}$, binding was consistent with its antagonism of U46619 but not with its activation of $\mathrm{G}$ proteins-the $K_{\mathrm{i}}$ values for $\mathrm{PTA}_{2}$ were 5- and 30-fold lower than $\mathrm{EC}_{50}$ values for $\mathrm{G}_{\mathrm{q}}$ and $\mathrm{G}_{13}$ activation (3 and 14 $\mu \mathrm{M}$, respectively). Variations in $\mathrm{Mg}^{2+}$ and/or the inclusion of guanosine $5^{\prime}$-( $\beta, \gamma$-imido)triphosphate or GTP $\gamma \mathrm{S}$ had no impact. Viewed from the perspective of concentration-response relationships, therefore, the activation of $\mathrm{G}$ proteins by $\mathrm{PTA}_{2}$ in platelet membranes was shifted rightward from binding. The Hill slopes for U46619 and $\mathrm{PTA}_{2}$ were $-0.85 \pm 0.10(n=$ $3)$ and $-1.25 \pm 0.16(n=6)$, respectively. These values were not statistically different from each other or from 1 ; however, the power of the analysis was not so high as to completely rule out a difference in the two slopes that might connote differences in cooperativity.

A rightward shift in an effect is almost always due to the relevance of two receptors differing in affinity for the ligand, in which the effect is achieved through the one having a lower affinity, but the binding is evident only for the one having the higher affinity for reasons of selectivity in radiolabeling or disproportionate levels of receptor. We turned to HEK 293 cells, therefore, to evaluate $\mathrm{TP} \alpha$ in isolation, aware that the receptor reserve implied above and elsewhere (Zhang et al., 2006), which would cause leftward shifts, might complicate the analysis. The binding data were quite similar to those of platelets. U46619 and $\mathrm{PTA}_{2}$ were comparable with each other in terms of affinities for $\mathrm{TP} \alpha$, having $K_{\mathrm{i}}$ values of 0.8 and $0.7 \mu \mathrm{M}$, respectively (Table 2). As anticipated for receptor reserve, the activation of $\mathrm{G}_{\mathrm{q}}$ and $\mathrm{G}_{13}$ by $\mathrm{U} 46619\left(\mathrm{EC}_{50} \sim 0.08 \mu \mathrm{M}\right.$ in HEK 293 cell membrane) was left-shifted from binding. Despite the reserve, the activation of $\mathrm{G}$ proteins by $\mathrm{PTA}_{2}\left(\mathrm{EC}_{50}\right.$ values $=1 \mu \mathrm{M}$ for $\mathrm{G}_{\mathrm{q}}$ and $4.5 \mu \mathrm{M}$ for $\mathrm{G}_{13}$ ) was not left-shifted; in fact, the activation of $\mathrm{G}_{13}$ remained right-shifted from binding. Therefore, two "different" receptors can be entertained as a basis for differences in binding and activation; however, the two would originate with $\mathrm{TP} \alpha$, presumably through different conformations. An alternative is that two sites for $\mathrm{PTA}_{2}$ exist on $\mathrm{TP} \alpha$, accounting for the duality in the actions of $\mathrm{PTA}_{2}$.

TABLE 2

Binding of ligands to TP

$K_{\mathrm{i}}$ values were determined for $\mathrm{SQ} 29548$, U46619, and $\mathrm{PTA}_{2}$ in displacement assays with $20 \mathrm{nM}\left[{ }^{3} \mathrm{H}\right] \mathrm{SQ} 29548$ using membranes prepared from human platelets and HEK 293 cells, in the latter case stably (over)expressing TP $\alpha$. Each assay was conducted with five or six concentrations of ligand in duplicate. Each reported value is the mean; 95\% confidence intervals, obtained by nonlinear regression on data accumulated from three or four experiments, are in parentheses.

\begin{tabular}{lcc}
\hline & \multicolumn{2}{c}{$K_{\mathrm{i}}$} \\
\cline { 2 - 3 } & Human Platelets & HEK $293 \alpha \mathrm{TP} \alpha$ \\
\hline & $\mu M$ & \\
SQ29548 $_{\text {U46619 }}$ & $0.04(0.03-0.06)$ & $0.07(0.05-0.10)$ \\
PTA $_{2}$ & $0.7(0.5-1.0)$ & $0.8(0.7-1.1)$ \\
\hline
\end{tabular}




\section{Discussion}

The $\mathrm{G}_{12}$ family has surfaced only rarely in the context of functional selectivity and always indirectly. The family is possibly involved in the selectivity exhibited through the 5-hydroxytryptamine ${ }_{2 \mathrm{C}}$ receptor in reference to phosphoinositide accumulation and arachidonic acid release (Berg et al., 1998), because RNA-edited forms of the receptor, which are uncoupled from the $\mathrm{G}_{12}$ family (Price et al., 2001), no longer exhibit selectivity (Berg et al., 2001). The family might also underlie the selectivity exhibited through the 5-hydroxytryptamine ${ }_{2 \mathrm{~A}}$ receptor, presuming the family again to be involved in arachidonic acid release (Berg et al., 1998; Kurrasch-Orbaugh et al., 2003). We are aware of no other possible examples. The paucity of information regarding the $\mathrm{G}_{12}$ family is not entirely unexpected, in that the actions of the family are not easily separated from those of other signaling entities nor easily quantified through regulation of second messengers, proximate enzymes, or ion channels. However, receptors coupled to the $G_{12}$ family are basic to cell function and, because they are invariably coupled to $\mathrm{G}$ proteins of other families, provide ample potential for selectivity.

We approached the need for uniquely linked and quantifiable effectors by measuring $\mathrm{G}$ protein activation directly, using agonist-promoted exchange of GDP for $\left[{ }^{35} \mathrm{~S}\right] \mathrm{GTP} \gamma \mathrm{S}$. The assay's utility in measurements of potency and efficacy has already been documented (Barr and Manning, 1997; Windh et al., 1999; Windh and Manning, 2002; Zhang et al., 2006), and extension to selectivity was made most recently for the dopamine D2 receptor in relation to subtypes of the $G_{i}$ family (Lane et al., 2007). The use of proximal effectors (i.e., $\mathrm{G}$ proteins) and cell membranes avoids pitfalls of nonlinearity and convergence in downstream signaling and superimposed forms of regulation that confound results in the intact cell. The choice in this study of $\mathrm{G}_{\mathrm{q}}$ and $\mathrm{G}_{13}$ for analysis was based on the large number of receptors that engage these two G proteins specifically (Riobo and Manning, 2005) and the relevance of both to platelet function (Offermanns et al., 1997; Moers et al., 2003; Offermanns, 2006).

We found that $\mathrm{G}_{\mathrm{q}}$ and $\mathrm{G}_{13}$ were, in fact, differentially engaged by agonists for TP $\alpha$. PTA 2 activated $\mathrm{G}_{\mathrm{q}}$ at lower concentrations than it did $\mathrm{G}_{13}$, whereas the converse was true for 8-iso- $\mathrm{PGF}_{2 \alpha}$. Selectivity for the two agonists was discerned in membranes of

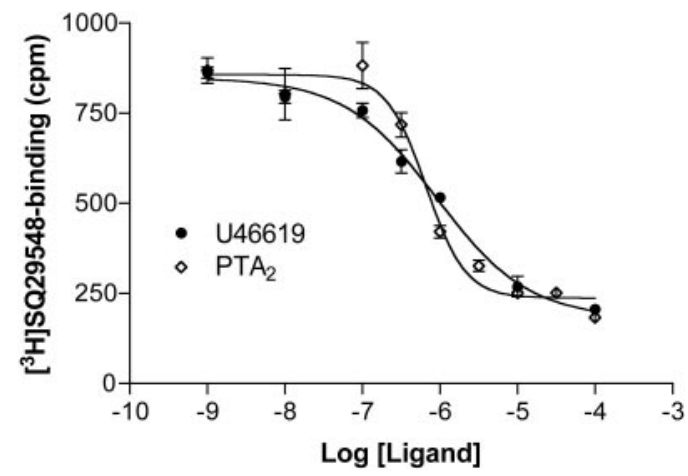

Fig. 5. Displacement of $\left[{ }^{3} \mathrm{H}\right] \mathrm{SQ} 29548$ from platelet membranes. Platelet membranes were incubated with $20 \mathrm{nM}\left[{ }^{3} \mathrm{H}\right] \mathrm{SQ} 29548$ in the absence or presence of increasing concentrations of $\mathrm{U} 46619$ and $\mathrm{PTA}_{2}$ for $30 \mathrm{~min}$ at $30^{\circ} \mathrm{C}$. Bound radiolabel was determined subsequently by filtration. Shown is a single experiment, performed in duplicate for each displacing ligand, which is representative of several others. both HEK 293 cells overexpressing $\mathrm{TP} \alpha$ and platelets. U46619, in contrast, exhibited no selectivity. The opposite $\left(\mathrm{PTA}_{2}\right.$ versus 8-iso- $\mathrm{PGF}_{2 \alpha}$ ) and nonselective (U46619) patterns of $\mathrm{G}$ protein engagement are important in precluding receptor reserve alone as a basis for the phenomenon.

Platelet rounding, a measure of $\mathrm{G}_{13}$ action, was elicited by all three ligands; however, aggregation, which requires $G_{q}$ as well, was elicited by U46619 alone through TP. This observation is consistent with our assertion that functional selectivity cannot always be detected through events downstream of $\mathrm{G}$ proteins. The more proximal the effector being measured to receptor, we believe, the more likely the measure is to be faithful to receptor conformation. We suspect for platelets that aggregation requires a threshold level of activated $G_{q}$, noting that neither $\mathrm{PTA}_{2}$ nor 8-iso- $\mathrm{PGF}_{2 \alpha}$ can achieve full activation of this $\mathrm{G}$ protein. It is noteworthy that the $\mathrm{EC}_{50}$ for U46619 in aggregation was congruent with the $\mathrm{EC}_{50}$ in activation of $\mathrm{G}_{\mathrm{q}}$ and the $K_{\mathrm{i}}$ for binding of $\mathrm{U} 46619$ to platelet membranes, suggesting little or no reserve of receptor or $G$ protein. This finding was in distinction to rounding, for which the concentration-response relationship appeared to be substantially left-shifted from $\mathrm{G}$ protein activation and binding, suggesting a reserve of receptor and/or receptor-activated $\mathrm{G}_{13}$. This observation is important-any nonselective ligand such as U46619 would trigger rounding at concentrations much lower than aggregation, an action that might be confused with true (functional) selectivity. Again, the choice of G proteins to evaluate selectivity is essential. The reserve here has nothing to do with, and does not impede, the deduction of selectivity using $\mathrm{G}$ proteins as endpoints.

In evaluating the properties of $\mathrm{PTA}_{2}$, we noted in platelets an antagonistic action for the ligand that did not conform to what would be expected for even a weak agonist; i.e., $\mathrm{PTA}_{2}$ blocked the actions of U46619 at concentrations well below those anticipated from the affinity suggested by its $\mathrm{EC}_{50}$ in $\mathrm{G}$ protein activation. We found that the $\mathrm{EC}_{50}$ values for activation of $\mathrm{G}_{\mathrm{q}}$ and $\mathrm{G}_{13}$ by $\mathrm{PTA}_{2}$ were, in fact, right-shifted from the apparent binding of the ligand: the $\mathrm{EC}_{50}$ for activation of $\mathrm{G}_{\mathrm{q}}$ was shifted from the $K_{\mathrm{i}}$ by approximately 8-fold, whereas that for activation of $\mathrm{G}_{13}$ was shifted by approximately 35fold. Differences between the $\left.{ }^{35} \mathrm{~S}\right] \mathrm{GTP} \gamma \mathrm{S}$-binding and displacement assays are unlikely to account for the shift, because buffer constituents in the activation assay (for example, $\mathrm{Mg}^{2+}$ and/or GTP $\gamma \mathrm{S}$ ) had no impact on displacement of $\left[{ }^{3} \mathrm{H}\right] \mathrm{SQ} 29548$. More compellingly, no meaningful shift was evident for U46619; the shift was unique to $\mathrm{PTA}_{2}$.

The almost universal explanation for a rightward shift of function from binding is the existence of two different receptors. The relevance of any receptor apart from $\mathrm{TP} \alpha$ itself, however, is doubtful. The receptor labeled with $\left[{ }^{3} \mathrm{H}\right] \mathrm{SQ} 29548$ in platelet membranes is mostly if not solely TP $\alpha$ (Habib et al., 1999). The rightward shift for activation of $\mathrm{G}_{13}$, moreover, is also noted in HEK 293 cells made to express $\mathrm{TP} \alpha$. The possibility of $\operatorname{TP} \beta$ might be entertained in platelets, but it cannot account for the results in HEK 293 cells. We suggest as one possibility, therefore, that $\mathrm{TP} \alpha$ itself resolves into two populations. $\mathrm{PTA}_{2}$ would bind to one as an antagonist with relatively high affinity and to the other as an agonist with lower affinity. The latter population would not be recognized by $\left[{ }^{3} \mathrm{H}\right] \mathrm{SQ} 29548$ binding because of low density (i.e., the population is beneath the threshold of detection by radiolabeling) or low affinity of the population for the radioligand, 
such that binding is not stable in the filtration assay. The existence of different populations of $\mathrm{TP} \alpha$ is easily posited. Populations can arise through heterodimerization, other forms of oligomerization, or free receptor versus that complexed to the assayed $\mathrm{G}$ protein. Populations might also arise by virtue of the receptor interacting with other proteins, perhaps "silent" $\mathrm{G}$ proteins (such as $\mathrm{G}_{\mathrm{i}}$ or $\mathrm{G}_{12}$ ), regulators of $\mathrm{G}$ protein signaling, or $\beta$-arrestin, or as a function of location within membrane (Zheng et al., 2008). Our data might also be explained by two sites for binding of ligands on $\mathrm{TP} \alpha$, one used by U46619 as an agonist and $\mathrm{PTA}_{2}$ as an antagonist, and the other by $\mathrm{PTA}_{2}$ as an agonist. We note the resemblance of our data for $\mathrm{PTA}_{2}$ with $\mathrm{TP} \alpha$ to those obtained by Baker et al. (2003) for CGP12177 with the $\beta_{1}$-adrenoreceptor, where distinct conformations or activation sites were similarly posited. Functional duality speaks to the possibility of selectivity apparent not so much at the level of one $G$ protein or another but at basic distinctions between agonism and antagonism.

The data obtained here for $\mathrm{TP} \alpha$ underscore functional selectivity in relation to the $G_{q}$ and $G_{12}$ families, the potential for reserves of receptor and/or $G$ protein that can mimic selectivity, and populations of a single receptor that relate to the agonistic properties of a ligand $\left(\mathrm{PTA}_{2}\right)$. All of these introduce a largely unrecognized and important complexity to the coordination of signaling noted for the $G_{q}$ and $G_{12}$ families. Remaining questions pertain to the basis of underlying conformations of receptor, specific links to events downstream of the $\mathrm{G}$ proteins, and extension to other receptors coupled conjointly to the two families.

\section{Acknowledgments}

We thank Cherisse DiLizio for her many technical contributions to this work.

\section{References}

Alvarez VA, Arttamangkul S, Dang V, Salem A, Whistler JL, Von Zastrow M, Grandy DK, and Williams JT (2002) $\mu$-Opioid receptors: ligand-dependent activation of potassium conductance, desensitization, and internalization. $J$ Neurosci 22:5769-5776

Baker JG, Hall IP, and Hill SJ (2003) Agonist actions of " $\beta$-blockers" provide evidence for two agonist activation sites or conformations of the human $\beta_{1}$ adrenoreceptor. Mol Pharmacol 63:1312-1321.

Barr AJ and Manning DR (1997) Agonist-independent activation of $\mathrm{G}_{\mathrm{z}}$ by the $5-\mathrm{HT}_{1 \mathrm{~A}}$ receptor co-expressed in Sf9 cells: distinguishing inverse agonists from neutral antagonists. J Biol Chem 272:32979-32987.

Berg KA, Cropper JD, Niswender CM, Sanders-Bush E, Emeson RB, and Clarke WP (2001) RNA-editing of the 5-HT2C receptor alters agonist-receptor-effector coupling specificity. Br J Pharmacol 134:386-392.

Berg KA, Maayani S, Goldfarb J, Scaramellini C, Leff P, and Clarke WP (1998) Effector pathway-dependent relative efficacy at serotonin Type $2 \mathrm{~A}$ and $2 \mathrm{C}$ receptors: Evidence for Agonist-directed trafficking of receptor stimululs. Mol Pharmacol 54:94-104.

Butkerait P, Zheng Y, Hallak H, Graham TE, Miller HA, Burris KD, Molinoff PB, and Manning DR (1995) Expression of the human 5-hydroxytryptamine ${ }_{1 \mathrm{~A}}$ receptor $^{-}$ in Sf9 cells. J Biol Chem 270:18691-18699.

Cordeaux Y, Nickolls SA, Flood LA, Graber SG, and Strange PG (2001) Agonist regulation of $\mathrm{D}_{2}$ domapine receptor/g protein interaction. J Biol Chem 276:2866728675

Cussac D, Newman-Tancredi A, Duqueyroix D, Pasteau V, and Millan MJ (2002) Differential activation of $\mathrm{Gq} / 11$ and $\mathrm{Gi}_{3}$ proteins at 5-hydroxytryptamine ${ }_{2 \mathrm{C}}$ receptors revealed by antibody capture assays: Influence of receptor reserve and relationship to agonist-directed trafficking. Mol Pharmacol 62:578-589.

De Deurwaerdère P, Navailles S, Berg KA, Clarke WP, and Spampinato U (2004) Constitutive activity of the serotonin $2 \mathrm{C}$ receptor inhibits in vivo dopamine release in the rat striatum and nucleus accumbens. J Neurosci 24:3235-3241.

Gay EA, Urban JD, Nichols DE, Oxford GS, and Mailman RB (2004) Functional selectivity of $\mathrm{D}_{2}$ receptor ligands in a Chinese hamster ovary $h \mathrm{D}_{2 \mathrm{~L}}$ cell line: evidence for induction of ligand-specific receptor states. Mol Pharmacol 66:97-105

Grynkiewicz G, Poenie M, and Tsien RY (1985) A new generation of $\mathrm{Ca}^{2+}$ indicators with greatly improved fluorescence properties. J Biol Chem 260:3440-3450.

Habib A, FitzGerald GA, and Maclouf J (1999) Phosphorylation of the thromboxane receptor $\mathrm{A}$, the predominant isoform expressed in human platelets. $J$ Biol Chem 274:2645-2651.
Keith DE, Anton B, Murray SR, Zaki PA, Chu PC, Lissin DV, Monteillet-Agius G, Stewart PL, Evans CJ, and von Zastrow M (1998) $\mu$-Opioid receptor internalization: opiate drugs have differential effects on a conserved endocytic mechanism in vitro and in the mammalian brain. Mol Pharmacol 53:377-384.

Keith DE, Murray SR, Zaki PA, Chu PC, Lissin DV, Kang L, Evans CJ, and von Zastrow M (1996) Morphine activates opioid receptors without causing their rapid internalization. J Biol Chem 271:19021-19024.

Kelly P, Casey PJ, and Meigs TE (2007) Biologic functions of the G12 subfamily of heterotrimeric G proteins: Growth, migration, and metastasis. Biochemistry 46 6677-6687.

Kilts JD, Connery HS, Arrington EG, Lewis MM, Lawler CP, Oxford GS, O'Malley KL, Todd RD, Blake BL, Nichols DE, et al. (2002) Functional selectivity of dopamine receptor agonists. II. Actions of dihydrexidine in $\mathrm{D}_{2 \mathrm{~L}}$ receptor-transfected MN9D cells and pituitary lactotrophs. J Pharmacol Exp Ther 301:1179-1189.

Kozasa T and Gilman AG (1995) Purification of recombinant G proteins from Sf9 cells by hexahistidine tagging of associated subunits. J Biol Chem 270:1734-1741. Kurrasch-Orbaugh DM, Parrish JC, Watts VJ, and Nichols DE (2003) A complex signaling cascade links the serotonin ${ }_{2 A}$ receptor to phospholipase $\mathrm{A}_{2}$ activation: the involvement of MAP kinases. J Neurochem 86:980-991.

Lane JR, Powney B, Wise A, Rees S, and Milligan G (2007) Protean agonism at the dopamine $\mathrm{D}_{2}$ receptor: ( $S$ )-3-(3-hydroxyphenyl)- $N$-propylpiperidine is an agonist for activation of $\mathrm{G}_{\mathrm{o} 1}$ but an antagonist/inverse agonist for $\mathrm{G}_{\mathrm{i} 1}, \mathrm{G}_{\mathrm{i} 2}$, and $\mathrm{G}_{\mathrm{i} 3}$. Mol Pharmacol 71:1349-1359.

Lawler CP, Prioleau C, Lewis MM, Mak C, Jiang D, Schetz JA, Gonzalez AM, Sibley DR, and Mailman RB (1999) Interactions of the novel antipsychotic aripiprazole (OPC-14597) with dopamine and serotonin receptor subtypes. Neuropsychopharmacology 20:612-627.

Moers A, Nieswandt B, Massberg S, Wettschureck N, Grüner S, Konrad I, Schulte V, Aktas B, Gratacap MP, Simon MI, et al. (2003). $\mathrm{G}_{13}$ is an essential mediator of platelet activation in hemostasis and thrombosis. Nature Med 9:1418-1422.

Mottola DM, Kilts JD, Lewis MM, Connery HS, Walker QD, Jones SR, Booth RG, Hyslop DK, Piercey M, Wightman RM, et al. (2002) Functional selectivity of dopamine receptor agonists. I. Selective activation of postsynaptic dopamine $\mathrm{D}_{2}$ receptors linked to adenylate cyclase. J Pharmacol Exp Ther 301:1166-1178.

Nicolaou KC, Magolda RL, Smith JB, Aharony D, Smith EF, and Lefer AM (1979) Synthesis and biological properties of Pinane-Thromboxane $\mathrm{A}_{2}$, a selective inhibitor of coronary artery constriction, platelet aggregation, and thromboxane formation. Proc Natl Acad Sci U S A 76:2566-2570.

Nie D, Guo Y, Yang D, Tang Y, Chen Y, Wang MT, Zacharek A, Qiao Y, Che M, and Honn KV (2008) Thromboxane A 2 receptors in prostate carcinoma: Expression and its role in regulating cell motility via small GTPase Rho. Cancer Res 68:115-121.

Offermanns S (2006) Activation of platelet function through G protein coupled receptors. Circ Res 99:1293-1304.

Offermanns S, Toombs CF, Hu YH, and Simon MI (1997) Defective platelet activation in $\mathrm{G} \alpha \alpha_{\mathrm{q}}$-deficient mice. Nature 389:183-186.

Perez DM and Karnik SS (2005) Multiple signaling states of G-protein-coupled receptors. Pharmacol Rev 57:147-161.

Prevost N, Woulfe D, Tanaka T, and Brass LF (2002) Interactions between Eph kinases and ephrins provide a mechanism to support platelet aggregation once cell-to-cell contact has occurred. Proc Natl Acad Sci U S A 99:9219-9224.

Price RD, Weiner DM, Chang MS, and Sanders-Bush E (2001) RNA editing of the human serotonin $5-\mathrm{HT}_{2 \mathrm{C}}$ receptor alters receptor mediated activation of $\mathrm{G}_{13}$ protein. J Biol Chem 276:44663-44668.

Riobo NA and Manning DR (2005) Receptors coupled to heterotrimeric G proteins of the $\mathrm{G}_{12}$ family. Trends Pharmacol Sci 26:146-154.

Ryman-Rasmussen JP, Nichols DE, and Mailman RB (2005) Differential activation of adenylate cyclase and receptor internalization by novel dopamine $\mathrm{D}_{1}$ receptor agonists. Mol Pharmacol 68:1039-1048.

Singer WD, Miller RT, and Sternweis PC (1994) Purification and characterization of the a subunit of $\mathrm{G}_{13}$. J Biol Chem 269:19796-19802.

Urban JD, Clarke WP, von Zastrow M, Nichols DE, Kobilka B, Weinstein H, Javitch JA, Roth BL, Christopoulos A, Sexton PM, et al. (2007) Functional selectivity and classical concepts of quantitative pharmacology. J Pharmacol Exp Ther 320:1-13.

Violin JD and Lefkowitz RJ (2007) $\beta$-arrestin-biased ligands at seven-transmembrane receptors. Trends Pharmacol Sci 28:416-422.

Whistler JL, Chuang HH, Chu P, Jan LY, and von Zastrow M (1999) Functiona dissociation of $\mathrm{m}$ opioid receptor signaling and endocytosis: Implications for the biology of opiate tolerance and addiction. Neuron 23:737-746.

Wilson SJ, Roche AM, Kostetskaia E, and Smyth EM (2004) Dimerization of the human receptors for prostacyclin and thromboxane facilitates thromboxane receptor-mediated cAMP generation. J Biol Chem 279:53036-53047.

Windh RT, Lee MJ, Hla T, An S, Barr AJ, and Manning DR (1999) Differential coupling of the sphingosine 1-phosphate receptors Edg-1, Edg-3, and H218/Edg-5 to the $\mathrm{G}_{\mathrm{i}}, \mathrm{G}_{\mathrm{q}}$, and $\mathrm{G}_{12}$ families of heterotrimeric $\mathrm{G}$ proteins. J Biol Chem 274: 27351-27358.

Windh RT and Manning DR (2002) Analysis of G protein activation in Sf9 and mammalian cells by agonist-promoted $\left[{ }^{35} \mathrm{~S}\right] \mathrm{GTP} \gamma \mathrm{S}$ binding. Meth Enzymol 344:3-14

Zhang L, DiLizio C, Kim D, Smyth EM, and Manning DR (2006) The $\mathrm{G}_{12}$ family of G proteins as a reporter of thromboxane $\mathrm{A}_{2}$ receptor activity. Mol Pharmacol 69: 1433-1440.

Zheng H, Chu J, Qiu Y, Loh HH, and Law PY (2008) Agonist-selective signaling is determined by the receptor location within the membrane domains. Proc Natl Acad Sci U S A 105:9421-9426.

Address correspondence to: David R. Manning, Department of Pharmacology, University of Pennsylvania School of Medicine, 3620 Hamilton Walk, Philadelphia, PA 19104-6084. E-mail: manning@mail.med.upenn.edu 